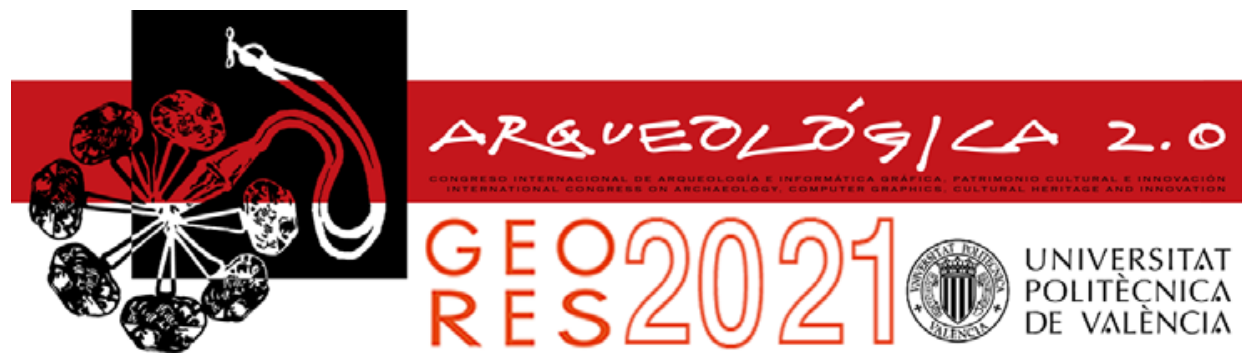

Proceedings of the joint international event $9^{\text {th }}$ ARQUEOLÓGICA

$2.0 \& 3^{\text {rd }}$ GEORES

Valencia (Spain).

26-28 April 2021

\title{
THREE-DIMENSIONAL SURVEY AND MATERIAL CHARACTERIZATION OF THE TEMPIO-MASSERIA DEL GIGANTE IN CUMAE
}

\author{
Raffaele Amore ${ }^{\mathrm{a},{ }^{*}}$, Federica Carandente ${ }^{\mathrm{b}}$ \\ a Department of Architecture, University Federico II of Naples, Viale Giacchino Rossini 33, 80055 Portici, Naples, Italy. \\ raffaeleamore@unina.it \\ ${ }^{\mathrm{b}}$ Department of Architecture, University Federico II of Naples, Via Antonio de Curtis 16, 80078 Pozzuoli, Naples, Italy. \\ fe.carandente@studenti.unina.it
}

\begin{abstract}
:
The following paper describes the work carried out from a University exercise of the Restoration Lab of the Architecture Department of the University of Naples Federico II. The work reflects the results of a Three-dimensional survey and metric characterisation of the 'Tempio-Masseria del Gigante', in Cumae, in the Naples province, to elaborate an architectural restoration project. This is a rural building from the XVIII century, built and extended by incorporating the rests of the cell of an ancient temple from the Flavian Age, located at the eastern border of Cumae lower city's Foro, that was called 'del Gigante' (of the Giant), since a large Jupiter's bust was found in its proximities. Well known in the world of antiquarian dealers, it was pictured in many drawings and landscape paintings since the end of the XVII century and the first half of the XVIII, the Masseria Temple is taken into exam had been acquired by the public domain only at the end of 1990 , so only after this period, the first archaeological investigations were made. Afterwards, between 1996 and 2002, conspicuous restoration and securing works were made. Today the structure is used as a temporary deposit for archaeological findings and it's among the buildings included in a wider restoration and re-functionalization project that has been proposed by the Campi Flegrei Archaeological Park and that is now about to start. The research work proposed is part of the preparatory analysis phase for the design of restoration work and has consisted of survey made with photo-modelling techniques with direct survey operations and it aimed to identify the construction methodologies and the degrading phenomena in place, with special regards to the identification of the ancient parts of the Temple, of those pertaining the conversion in a farmhouse and, lastly, those realised during the restoration works. The constant reference between the results of the threedimensional survey performed and those of the comparative analysis of historical iconography and the graphs and photos examined, has allowed reconstructing the history of the ancient and recent transformations of the building in order to define an integrated knowledge framework, necessary for the definition of suitable conservative strategies.
\end{abstract}

Keywords: cultural heritage, restoration, 3D reconstruction

\section{Introduction}

During the last century, the archaeological excavation operations made in Cumae's lower city were focused in the Foro's eastern sector, that brought to light the Capitolium, the Thermal Baths, the ruins of the southern buildings and of the so-called Temple with the Portico (Maiuri, 1927; Maiuri, 1958; Barrella, 2019). The Masseria del Gigante Temple wasn't involved in systematic archaeological research until 1994. Since that date, thanks to the Kyme project of the Federico II University, essays and surveys have been made, allowing the identification of the number of ancient structures of the Temple, without removing those of the more recent farmhouse (Gasparri \& Greco, 2007; Gasparri \& Greco, 2009). Following this investigation, restoration and securing works were made between 1995 and 2003. Unfortunately, these haven't been followed by a suitable re-functionalization of the complex, with the result that today only a few areas are used as a deposit of archaeological findings and the overall preservation of the building is mediocre. Recently the Campi Flegrei Archaeological Park has started a public call for projects called Restoration, securing and enhancement of the archaeological sites of Cumae's lower city, which is currently being awarded and that implies, among many actions, the re-functionalization of the Tempio-Masseria del Gigante. Taking this into account, the following paper, elaborated during the activities of the Restoration Lab of the Architecture Department of the University of Naples Federico II, after a historical framing, illustrates the results from the survey made at the Tempio-Masseria del Gigante, done with photo-modelling techniques integrated with direct measurements. The work has been designed with a precise objective: identifying the surviving parts of the ancient temple, those pertaining the 
conversion in a farmhouse and those realised during the restoration works made recently, always relying on previous studies on the matter. All this to recreate the scheme of the material documents and traces that today characterise this important and multi-layered monument and its decaying state.

The survey and documentary research carried out, in a logic of continuous integration and osmosis, have made it possible to highlight and consider the infinite diversity of the elements that make up the masonry of the TempleMasseria and to record the traces that history has imprinted on its subject; an interweaving of knowledge that is indispensable to direct the restoration project in an effectively conservative vision, able to preserve the material authenticity of what remains, also taking due account of the needs of material integration to ensure its stability and use.

\section{Cumae Archaeological Park}

The Archaeological evidence of Cumae are among the most ancient between those known in the Campi Flegrei area (Caputo, Morichi, Pane, \& Rispoli, 1996; Valenti, 2016). The Euboic column of Kyme was founded in the second quarter of the VIII century BC, within an area where the primitive Oscan town existed, made of nuclear residential settlements spread on the Cumaean plain and at the Acropolis' foothill. Modelled on the greek city structure, it was relevant during the Early Archaic age, extending its hegemony from the Licola plain to Miseno. Similarly, to Pithekoussai, on the Island of Ischia. Kyme had a central role in the maritime trade. In $421 \mathrm{BC}$ it was conquered by the Samnites, who dominated it for about a century, until $334 \mathrm{BC}$ when it became colonia sine suffragio of Rome. Following the transformations from the Samnites Era, further alterations were made during the Roman domination. The sacred buildings and the walls were largely transformed: the area of the ancient agorà was transformed in the city Foro, that would suffer several transformations during the centuries. In its shape, traceable back to the Imperial Age, it was characterised by the presence of a large rectangular and colonnaded square, paved with limestone and on which all the main monuments of the city were facing, such as the Tempio con Portico and the Capitolium, the tabernae and the commercial spaces. The colonnade was articulated on two levels, with a first-order supported by Doric columns and a second one with lonic columns.

Later, Octavian Augustus commissioned important engineering works to Agrippa and Cocceio Aucto in order to enhance the military role of the whole area of the Campi Flegrei: were so realised the Roman Crypta, the Cocceio Cave and the Sibilla Cave, that linked the portal area of Cumae to the Avernum and from there to the Portus lulius in Lucrino. During the Flavian Age the road Domitiana and the majority of the city structures were built. Following the Fall of the Roman Empire, years of decadence and neglect ensued. Since the III century AD until the Middle Age, a series of flooding's radically changed the consistence of Cumae's lower city that after the following raising of the walking surfaces was transformed into a productive area destined to artisanal activities and for the processing of glass and metal. (Gasparri \& Greco, 2007; Gasparri \& Greco, 2009). During the Byzantian era a cocciopiesto road was built, to cross the foro's square horizontally, in order to reach the Northern side of the
Capitolium. In those same years several calcare (limestone klin) were made: the most majestic one was located near the foro, including part of the so-called 'sillana room'. During the late ancient era the lime production became a very profitable activity thanks to the great amount of raw materials that were taken from the marble coatings and statues, still present in the Foro. During the same time, the main temples of the Acropolis from the Greek era were transformed into Paleochristians basilicas; the Roman Crypta and the Sybilla Cave were used to establish places of worship and burials (Maiuri, 1934).

\section{The archaeological structures and the hypotheses on its original articulation}

The analysis of the ancient structures found, partly incorporated and reused in the rooms of the Masseria, partly re-emerged during excavation campaigns carried out at the beginning of the $21^{\text {st }}$ century, and integrated with that of the marble finds recognized as belonging to the same complex, have allowed the archaeologist Flavia Coraggio to elaborate a hypothesis for the reconstruction of the temple and its decorative part. According to the reconstruction of the aforementioned scholar, it is a temple located within a sacred enclosure consisting of a three-armed portico, probably dedicated to Vespasian. The internal scanning of the space responds - according to the model of the Forum of Augustus - to an accurate tripartition distributed on the longitudinal axis, that is a large vestibule accessible from three entrances, the uncovered courtyard and, finally, the sacred building raised on a podium (Coraggio, 2007; Coraggio, 2013).

The temple was oriented along the east-west axis and was divided into a hexastyle pronaos with two columns on the sides, accessible by a flight of eleven steps; the last two steps are interrupted by the foundation plinths of the colonnade. Since the width of the cell exceeded that of the pronaos, Coraggio hypothesized that they were made up of two disjoint bodies, also treated differently from the point of view of the surface covering (Figs. 1, 2, \& 3). The podium was covered with marble, while the external volume of the peribulum was finished with a layer of cocciopesto; in elevation, the pronaos was covered in marble, while the walls of temple cell were covered in plaster. The three porticoed arms enclosed only the pronaos, leaving the outside temple cell at the peribulum. On the opposite side of the portico there were the three entrances that allowed access. The columns stood on composite attic bases and was made of smooth stems of cipollino marble, whose rhythm is documented by the trachyte foundation blocks, surmounted by composite capitals. The entire monumental complex is built in mixed masonry consisting of opus reticulatum and opus latericium. The cell of the temple, in particular, was characterized by the presence of opus reticulatum with toothing of latericium, as well as by walls in opus vittatum mixtum with alternating applications of parallelepiped blocks and bricks. Horizontal bands of opus latericium run along the walls, without a precise design (Coraggio, 2013). 


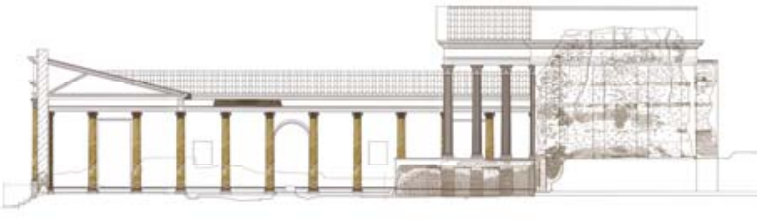

Figure 1: Tempio-Masseria del Gigante, Cuma. Longitudinal section according to the reconstructive hypothesis of $\mathrm{F}$. Coraggio, in Coraggio (2007), annexe L.

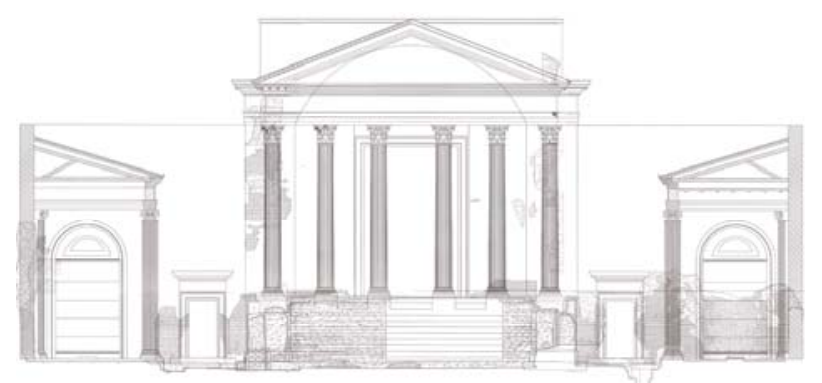

Figure 2: Tempio-Masseria del Gigante, Cuma. Pronaos prospectus according to the reconstructive hypothesis of $F$. Coraggio, in Coraggio (2007), annexe I.

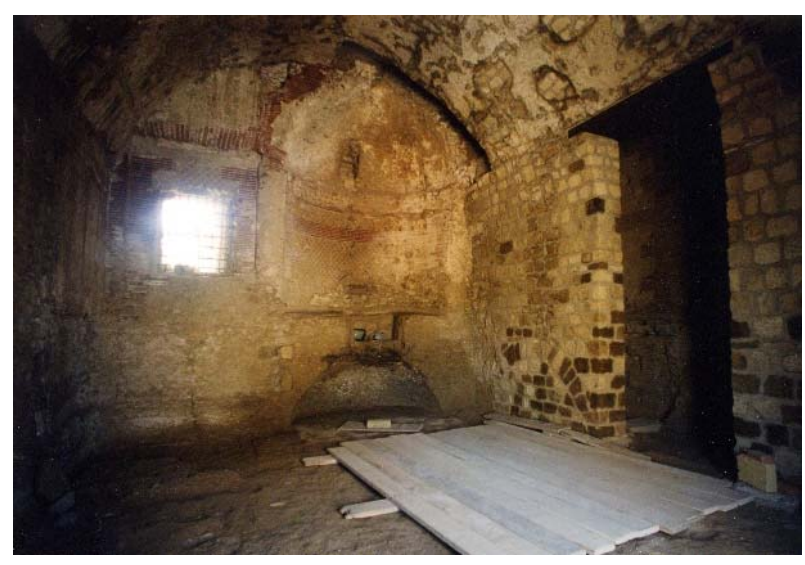

Figure 3: Tempio-Masseria del Gigante, Cuma. The apse before the restoration work 1994, photos by R. Morichi.

\section{The Temple-Masseria dei Giganti}

Literary sources testify that statuary and epigraphic material was found in the ancient settlement of Cuma as early as the Middle Ages (De Filippis, 1996a; 1996b). However, only from the beginning of the seventeenth century were undertaken specific excavation activities, with the aim of recovering valuable ancient materials. The Tempio-Masseria owes its name to the discovery in its vicinity of the so-called 'Giant' of the Palace: the torso of the colossal acrolithic statue of Jupiter, which was originally located in the nearby Capitolium. Among the many rural buildings built in the area on partially emerging ancient ruins (Caputo, 2015), the Tempio-Masseria del Gigante has been for centuries a significant architectural emergence and an immediate topographical point of reference for the entire area of ancient Cuma, represented in many paintings and performances of travellers and scholarly.

As the view by Filippo Morghen showed, at least until 1740 , the barrel vault of the cell was perfectly preserved, as well as the lacunars: only a few years later, probably following a fire, it collapsed (Figs. 4, 5).

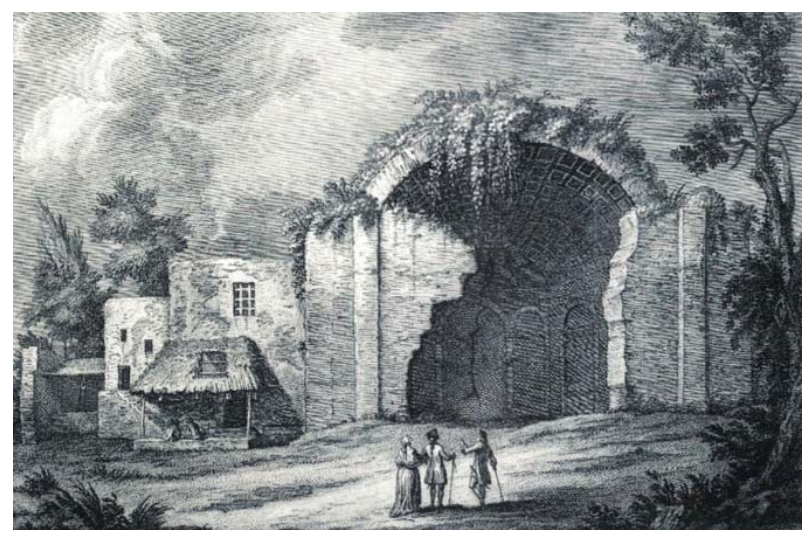

Figure 4: Morghen F, Parete anteriore del precedente Tempio di Giove nella via di Cuma. In Morghen 1814, tav. 28.

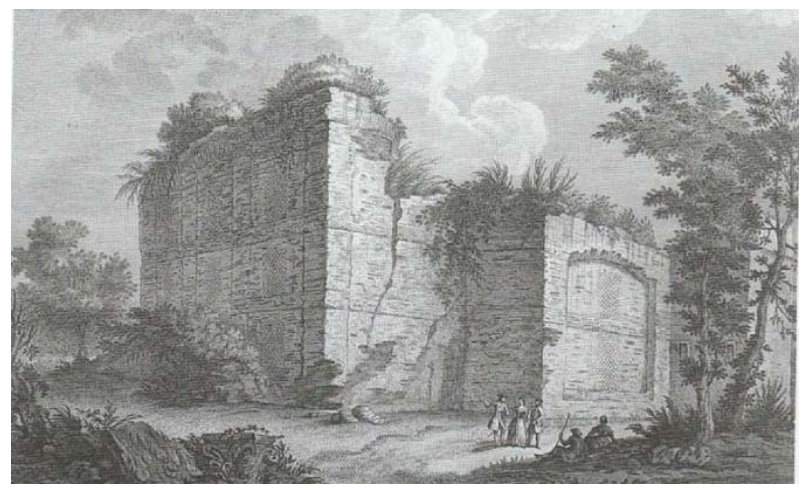

Figure 5: Morghen F., Parte posteriore d'un tempio nella via dell'antica Cuma: da molti creduto sacro a Giove. In Morghen 1814, tav. 27.

Then it was realized a new vault. It was set on the original wall to the north and on a new wall parallel to the original one, to the south, since the ancient one was no longer considered safe. This led to a significant reduction of the ancient volume. Throughout the eighteenth and nineteenth centuries, there were many discoveries and thefts of precious marble from the area of the forum: we will have to wait for Prince Leopoldo Borbone, Count of Syracuse, who was the first one on showing interest in recording the first systematic archaeological searches. They started right from the Temple- Masseria, of which part of the structures of the enclosures and its entrances were brought to light. Subsequently, and throughout the twentieth century, the Tempio-Masseria was volumetrically enlarged by the owners and actually nobody really cared about studying it. The interest of the scientific community of the time was entirely directed to the major excavations in the western sector of the Forum (Figs. 6, 7).

\section{The three-dimensional survey}

After completing the necessary historical documentary investigations, synthetically described here, the work carried out consisted of surveying the complex with the photo modelling technique, integrated with direct measurements of the construction details. The threedimensional survey carried out benefited from preexisting topographic measurements which made it 
possible to verify the degree of accuracy that was very high. 233 photographic shots from drone have been used, georeferenced by GPS antenna. These photos were taken according to three distinct shooting plans at different heights, made all around the building and then subsequently treated with a three-dimensional photo modelling program. Once aligned with the photos, there was a first cloud of the rough points that we proceeded to clean up manually. Subsequently, a dense cloud was generated and, from this, a three-dimensional polygon mesh from which the orthophotos of the elevations were extracted. From the three-dimensional model (Figs. 8, 9, 10 , \& 11), various section plans were obtained and exported to additional computer-assisted drawing programs, to elaborate plans and sections. For the completion of these graphs, a series of direct surveys have been carried out, room by room. In particular, the survey of many construction details and individual masonry parts of the interior rooms and some sample areas outside was carried out, also to verify the correctness of the photo modelling process.

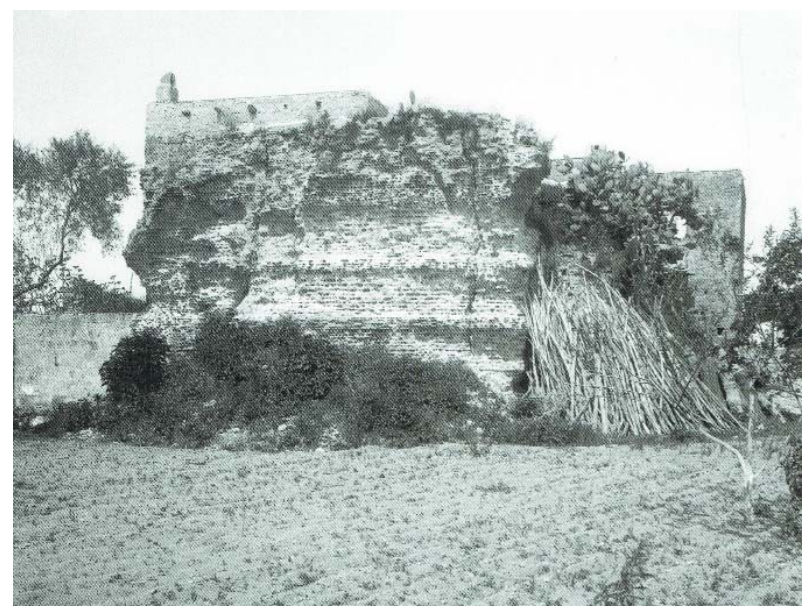

Figure 6: Tempio-Masseria del Gigante, Cuma. Archivio fotografico Mann, 3073, ex C165, 1938 in Valenti 2016, p.108.

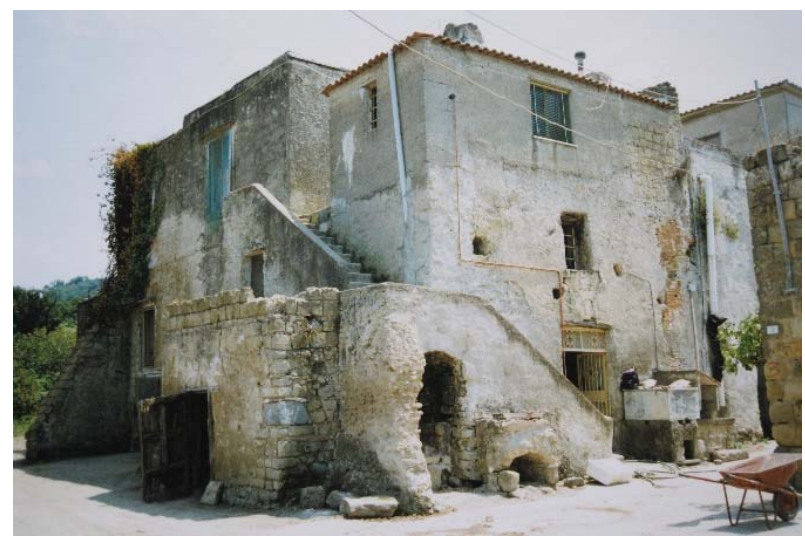

Figure 7: Tempio-Masseria del Gigante, Cuma. View of the north-west corner before the restoration work 1994, photos by

$$
\text { R. Di Re. }
$$

The graphic and photographic documentation produced was subsequently compared with the pre-existing one, made before the restoration works implemented. We proceeded, therefore, to identify the effective consistency of the consolidation and integration works completed and to evaluate their impact on the overall conservation of the archaeological artefact.

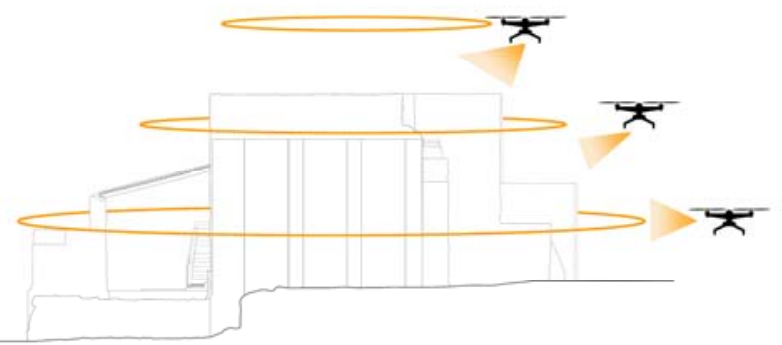

Figure 8: Tempio-Masseria del Gigante, Cuma. 3D model. The flight phases of the drone.

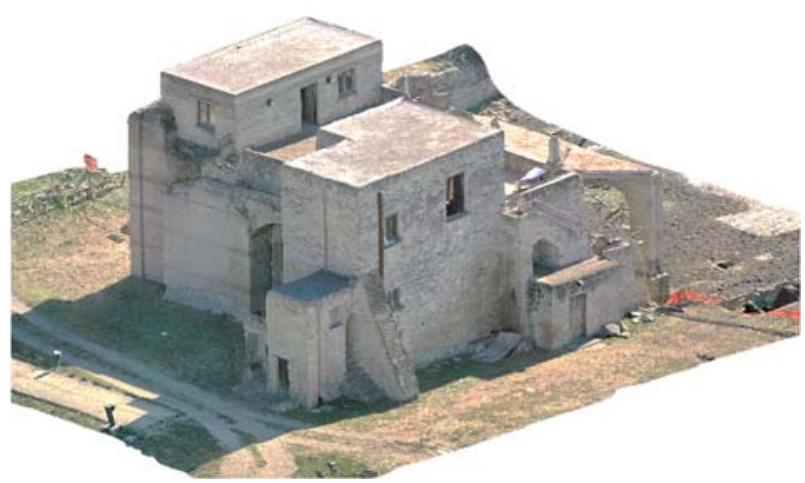

Figure 9: Tempio-Masseria del Gigante, Cuma. 3D model. View from the northeast.

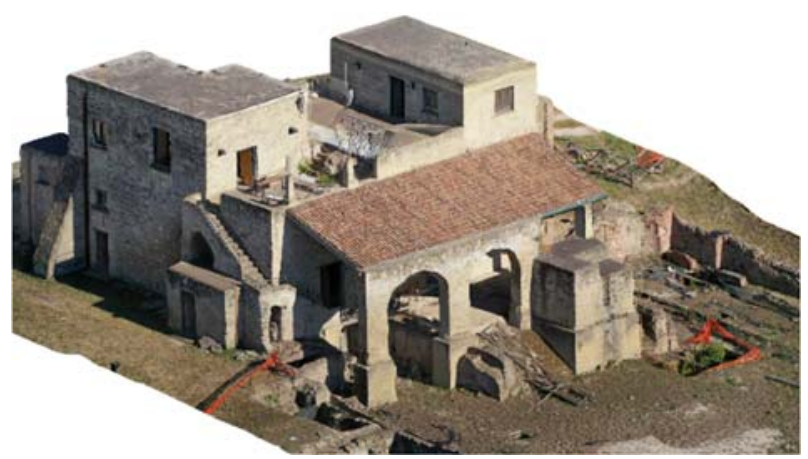

Figure 10: Tempio-Masseria del Gigante, Cuma. 3D model. View from the northwest.

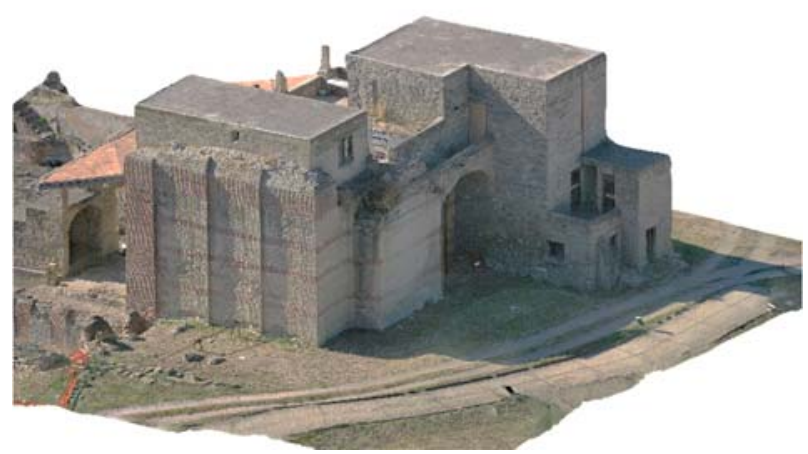

Figure 11: Tempio-Masseria del Gigante, Cuma. 3D model. View from the southeast. 


\section{Some considerations on recent restoration work}

That said, the comparison between the current state of The Temple-Masseria and the one prior to its restoration - that was possible to obtain by the historical-iconographic investigation, the three-dimensional surveys and the direct observation of the monument - leads to a series of critical observations on what has been accomplished. That is, about the nature and the number of wall integrations carried out and about the quality of the additions of new structural and functional elements, both in architectural terms and in terms of durability. The wall integrations performed, for example, were excessive (Figs. 12, 13, \& 14). Let's take for example what was done to consolidate the remains of the southern wall of temple cell. Probably due to structural necessity, the whole original wall was covered by a new wall structure: that was, by a physically-mechanical standpoint, a 'distinguished' and 'compatible' integration, but at the same point also irreversible and invasive.

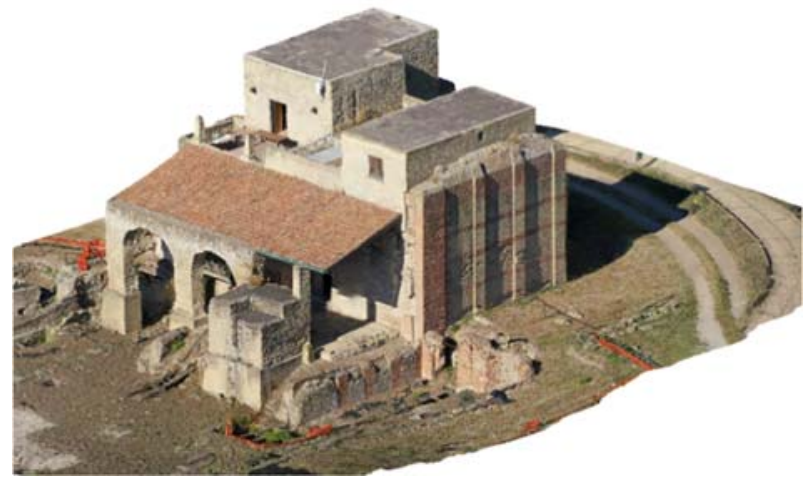

Figure 12: Tempio-Masseria del Gigante, Cuma. 3D model. View from the southwest.

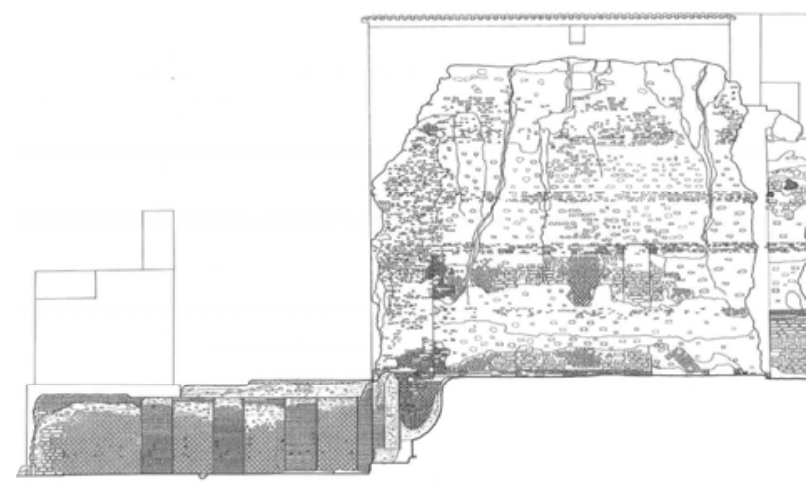

Figure 13: Tempio-Masseria del Gigante, Cuma. South prospectus, before restoration work, in Coraggio (2007), annex $\mathrm{F}$.

The typologies of consolidation of the vaults and wooden floors cannot be fully shared, because of the techniques based on reinforced concrete that do not guarantee instead the complete physical-mechanical compatibility of the additions with the existing structures (Fig. 15). Unfortunately, the rigour of the archaeological explorations and the richness of the revealed schedule has not been followed by consolidation and integration works that respect the authentic consistency of the complex. At this point, it seems legitimate to ask if it could have been possible to have adopted alternative solutions, in order to give more regard to the ruins of the walls and their stratifications or, at least, of being less invasive. Other misgivings are about the choices related to the finishing works (Figs. 16, 17, \& 18). Fixtures, handrails, railings, gratings, walls and so on have been made in ways and shapes that only respond to functional needs, renouncing any attempt to make a connection between the ancient and contemporary element. This was, in our opinion, an incomprehensible choice, which assumes the belief that in the archaeological field what needs to be added must be anonymous and devoid of all those qualities that are not so strictly related to the functionality. This point is flatly denied by the fact that, a little less than twenty years after their realization, these elements are the ones that more than the others have suffered a rapid degradation process. Furthermore, we can't ignore that the lack of a clear purpose of the use of the complex has led to a general 'aging' of all the parts, old and new, due to lack of maintenance.

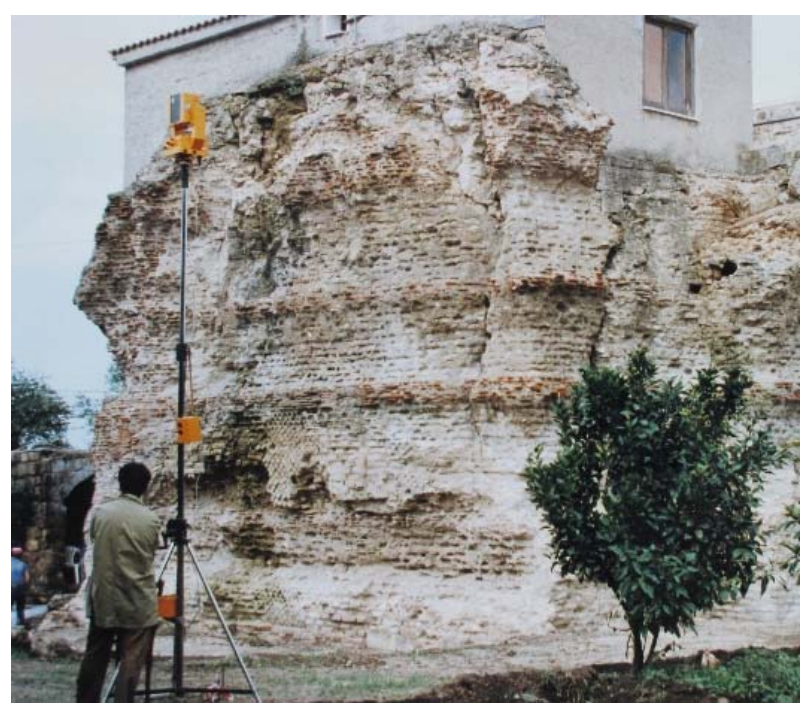

Figure 14: Tempio-Masseria del Gigante, Cuma. South prospectus, before restoration work 1994, photos by R. Di Re.

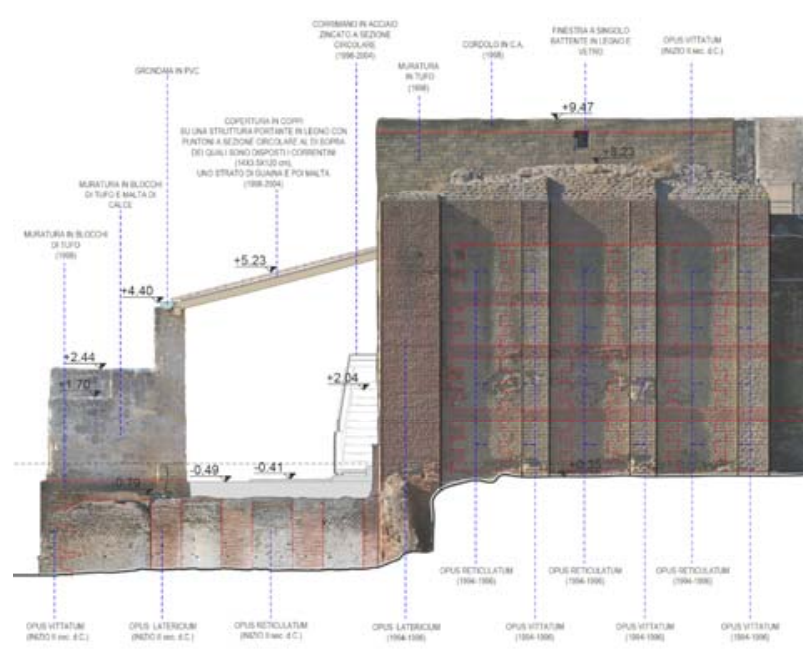

Figure 15: Tempio-Masseria del Gigante. South facade. Classification of the masonry typologies. 


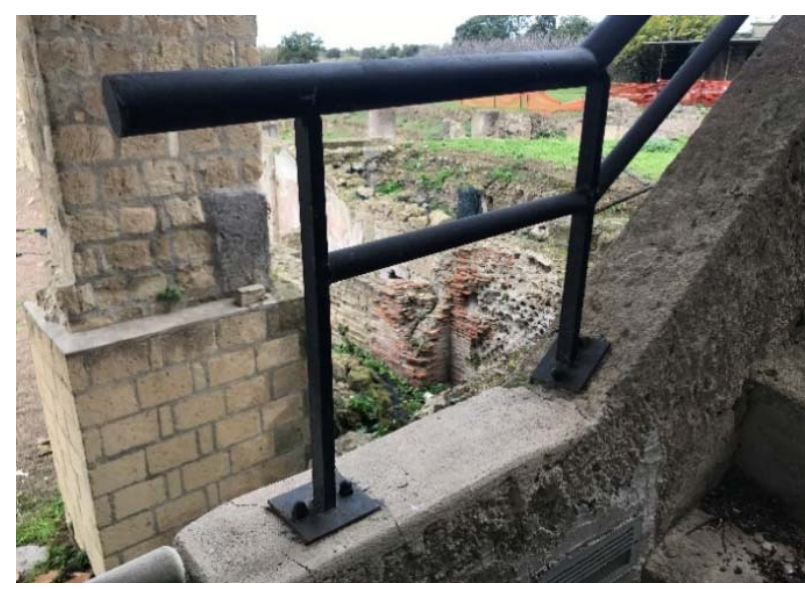

Figure 16: Tempio-Masseria del Gigante. The metal handrail of the staircase.

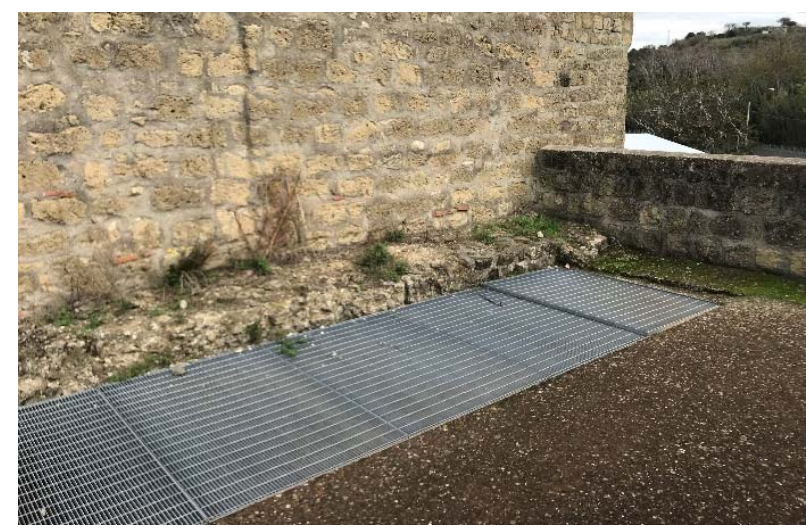

Figure 17: Tempio-Masseria del Gigante, Cuma. The grid for collecting rainwater on the terrace.

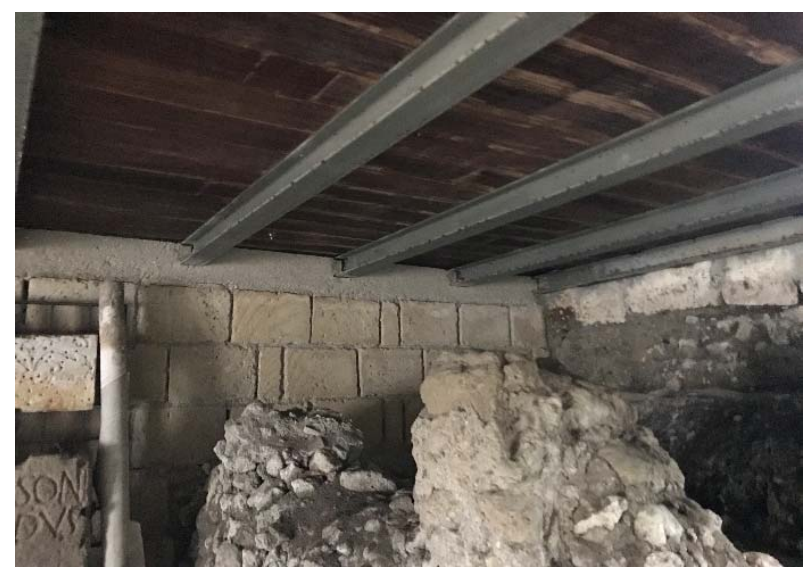

Figure 18: Tempio-Masseria del Gigante, Cuma. The floor in putrelles and wood.

\section{Conclusions}

The essays, studies, and archaeological surveys of such stratified monuments as the one in question allow us to reveal complex and articulated palimpsests, which tell us about millenary events through the overlapping and integration of the walls. However, it is an extremely fragile palinsesto: ensuring its safeguarding requires that immediately after the archaeological studies, we proceed - with the same care and attention - to identifying suitable restoration interventions necessary to guarantee its conservation and protection. Therefore, to the structural and conservative fragility of archaeological structures it must be answered with recognizable and limited additions "to the minimum that will be necessary to guarantee the conservation of the monument and restore the continuity of its forms" (art. 15 Charter of Venice). From here the need to operate in a synergistic and multidisciplinary manner. All the skills of the archaeologist must put beside those of the restorer architect and of all the specialists who - within a clear framework of skills and roles - may be able to provide useful information to achieve the aforementioned objectives

The resulting design and executive choices, in addition to being distinguishable and limited, in order to do not irremediably alter the authenticity and the flagrance of the archaeological data, must also be characterized by effective durability over time, otherwise, they would be useless. To these, which are prerogatives that are generally found for all maintenance and restoration interventions in archaeological areas, for structures such as the Tempio-Masseria del Gigante in Cuma, it is also necessary to add formal and functional integration operations, to ensure them an appropriate and conscious use and a respectful consideration of the stratifications detected. In these cases, in addition to revealing all the layers (strata), reading their sedimentations and recognizing their structures, their age and their consistency, it is also necessary to design all the additions necessary for their use and their formal reconfiguration, if necessary. And this, not to the detriment of this or other structures, but with the aim of making it readable as much as possible, in the full awareness that each design act that will be carried out will represent another text that will be added to the existing ones, inevitably determining a new order.

Within these methodological premises, the investigation and research carried out for the realization of this work reinforce the conviction that only an interdisciplinary approach is the tool to increase the fertile hermeneutic circle necessary to guarantee authentic conservation of historical materials and to define conservative strategies and enhancement of cultural heritage both in the architectural historical and archaeological fields. Threedimensional photomodelling techniques represent, in this framework of investigations, an extraordinarily useful and fast tool of knowledge that, when engaged in a broader process of cognitive deepening, can provide results of great importance to reveal the complexity of the values kept in the ancient masonry of archaeological monuments.

\section{References}

Barrella, N. (2019). Amedeo Maiuri e "l'invenzione" del parco archeologico di Cuma. Opportunismo e opportunità di un funzionario statale durante il Ventennio/Amedeo Maiuri and the" invention" of the archaeological park of Cuma. Opportunism and opportunity of a state official during Fascism. IL CAPITALE CULTURALE. Studies on the Value of Cultural Heritage, (9), 199-233. http://dx.doi.org/10.13138/2039-2362/2184 
Caputo, P., Morichi, R., Pane, R., \& Rispoli, P (1996). Cuma e il suo parco archeologico. Un territorio e le sue testimonianze. Scienze e Lettere, Roma.

Caputo, P. (2015). Masserie e paesaggio storico-archeologico dei Campi Flegrei. Tutela, conservazione e valorizzazione. In I Campi flegrei. L'architettura per i paesaggi archeologici, P. Miano, F. Izzo, L. Pagano, Eds. Quodlibet, Macerata.

Coraggio, F. (2007). La Masseria del Gigante. In Studi Cumani, 1. Cuma. Il foro. Scavi dell'Università di Napoli Federico II, 2000-2001. Atti della Giornata di studi, Naples, 22 June 2002 (Eds). C. Gasparri, G. Greco. Naus editoria, Napoli.

Coraggio, F. (2013). II tempio della Masseria del Gigante a Cuma. Quaderni del Centro Studi Magna Grecia 17, Studi Cumani 4. Naus editoria, Pozzuoli.

De Filippis, A. (1996a). Gli scavi dal XVII secolo alla Raccolta Cumana del Conte di Siracusa. In I Greci in Occidente, La Magna Grecia nelle Collezioni del Museo Archeologico di Napoli. Electa Napoli. Napoli, pp. 215-222.

De Filippis, A. (1996b). Gli scavi cumani di Emilio Stevens e la collezione Stevens. In I Greci in Occidente, La Magna Grecia nelle Collezioni del Museo Archeologico di Napoli. Electa Napoli. Napoli, pp. 233-240

Gasparri, C., \& Greco, G. (2007). Studi Cumani, 1. Cuma. II foro. Scavi dell'Università di Napoli Federico II, $2000-2001$. Atti della Giornata di studi, Naples, 22 June 2002. Quaderni del Centro Studi Magna Grecia. Naus editoria, Napoli.

Gasparri, C., \& Greco, G. (2009). Studi Cumani, 2. Cuma. Indagini archeologiche e nuove scoperte. Atti della Giornata di studi, Naples, 12 december 2007. Quaderni del Centro Studi Magna Grecia. Naus editoria, Pozzuoli.

Maiuri, A. (1927). Gli ultimi scavi di Cuma e l'epopea virgiliana. In Nuova antologia, 16, 489-199.

Maiuri, A. (1934). Monumenti cristiani di Cuma. In Atti del II Congresso Internazionale Archeologia Cristiana (Ravenna 2530 settembre 1932). Pontificio istituto di archeologia cristiana, Roma, pp. 217-231.

Maiuri, A. (1958). I Campi Flegrei. Dal Sepolcro di Virgilio all'antro di Cuma, Libreria dello Stato, Roma.

Valenti, R. (2016). I Campi Flegrei oltre il visibile. Artstudiopaparo, Napoli. 